\title{
GENIC ANALYSIS OF RESISTANCE TO BLAST DISEASE IN RICE ${ }^{10}$

\author{
(BY BIOMETRICAL GENETIC METHOD)
}

\author{
Hiko-Ichi OKa and Keh-Ming LiN \\ National Institute of Genetics, Japan and Taichung Agricultural \\ Improvement Station, Formosa.
}

Received August 22, 1956

UDC $575.113: 576.8 .097$.

$31: 582.542 .: 633.18$

The inheritance of resistance to blast disease (Piricularia oryzeae) in rice has been investigated by Sasaki (1923), Nakatomi (1926), Ramiah and Ramaswami (1936) and Hashioka (1950), and has been reviewed by the last author. These workers have shown that in most cases the resistance is controlled by one or two pairs of genes. and the gene for resistance is dominant over its allelomorph for susceptibility. In these former works, however, the genes were judged only from the pattern of variation in the degree of infection or in the number of lesions among $F_{2}$ plants or $\mathrm{F}_{3}$ families. If the frequency distribution appears to be discontinuous, the genes. can be easily detected by such a method. Actually, it often appears to be continuous, as the degree of infection is ready to fluctuate according to environmental conditions. Then, the genic analysis cannot stand on trustworthy evidence. From this viewpoint, the writers tried to employ biometrical methods for looking into the inheritance of blast disease resistance.

\section{Materials and Methods}

The $\mathrm{F}_{2}, \mathrm{~F}_{3}$ families and $\mathrm{F}_{3}$ bulk population of a varietal cross, Pei-ku $\times$ Taichung No. 65 were used as materials. Pei-ku is a Formosan native variety of first-crop nature (insensitive to day-length), belonging to the so-called Indica or "Continental group" (Oka 1953 d) ; Taichung No. 65 is a representative of the "Horai" or improved Japanese varieties, belonging to the so-called Japonica or " Temperate-Insular group". The $F_{1}$ showed semi-sterility, pollen fertility being 43\%. In the first crop of 1954, the materials were grown at Tonhsu, Taichung Prefecture, Formosa, where blast disease prevails seriously every year.

The $F_{2}, F_{3}$ bulk population, a mixed population of the parental varieties, rows of $\mathrm{F}_{3}$ families and parental varieties (the latter two were randomized) were planted in an experimental field fertilized with a high dosage of nitrogen, and were exposed to natural infection. The numbers of plants and families are shown in Table 1. The degree of infection was observed on a single plant basis, on May 10 and May 20. The pooled data of the repeated observations will be dealt with in this paper, though the repetition may be used as replication. The degree of infection was shown by the following index-numbers.

1) Contribution from the National Institute of Genetics, No. 174. 


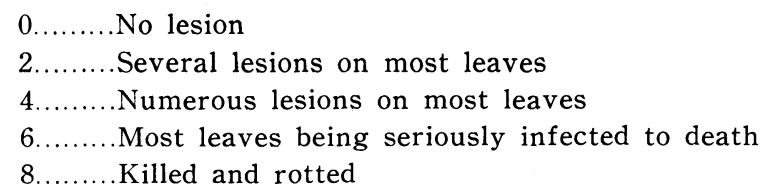

Table 1. Means and variances in $\mathrm{F}_{2}, \mathrm{~F}_{3}$ and parental varieties of Pei-ku $\times$ Taichung No. 65 .

\begin{tabular}{|c|c|c|c|c|c|}
\hline Plots & $\begin{array}{c}\text { Num. of } \\
\text { Plants }\end{array}$ & $\begin{array}{l}\text { Num. of } \\
\text { lines }\end{array}$ & Mean & $\begin{array}{l}\text { Variance } \\
\text { Lines }\end{array}$ & $\begin{array}{l}\text { among } \\
\text { Indv.'s }\end{array}$ \\
\hline $\begin{array}{ll}\mathrm{P}_{1} & \text { Rows } \\
\text { Bulk }\end{array}$ & $\begin{array}{l}89 \\
38\end{array}$ & 9 & $\begin{array}{l}1.056 \\
1.052\end{array}$ & $\begin{array}{c}0.0053 \\
-\end{array}$ & $\begin{array}{l}0.0538 \\
0.0512\end{array}$ \\
\hline $\begin{array}{ll}\mathrm{P}_{2} & \begin{array}{l}\text { Rows } \\
\text { Bulk }\end{array}\end{array}$ & $\begin{array}{l}87 \\
40\end{array}$ & $\underline{9}$ & $\begin{array}{l}6.080 \\
6.325\end{array}$ & $\begin{array}{c}0.1309 \\
-\end{array}$ & $\begin{array}{l}0.6219 \\
0.7891\end{array}$ \\
\hline $\mathrm{F}_{2}$ & 58 & - & 5.552 & - & 3.1289 \\
\hline $\mathrm{F}_{3} \begin{array}{l}\text { Lines } \\
\text { Bulk }\end{array}$ & $\begin{array}{l}754 \\
200\end{array}$ & $\underline{76}$ & $\begin{array}{l}5.758 \\
4.995\end{array}$ & 2.7076 & $\begin{array}{l}1.6194 \\
4.0754\end{array}$ \\
\hline
\end{tabular}

\section{Results of Observations}

\section{Frequency distributions of the index-number for resistance and a scaling test.}

As shown in Fig. 1, frequency distributions of the index-number for resistance appeared to be continuous in $\mathrm{F}_{2}$ as well as in $\mathrm{F}_{3}$; direct detection of underlying genes may then be impossible. As the number of highly resistant plants or families (with small index-numbers) is very small, the gene for resistance seems to be recessive in this cross. Means and variances of the index-number in respective plots were then calculated for biometrical analysis. Table 1 gives the results. With these figures, a scaling test was conducted, first, in order to find

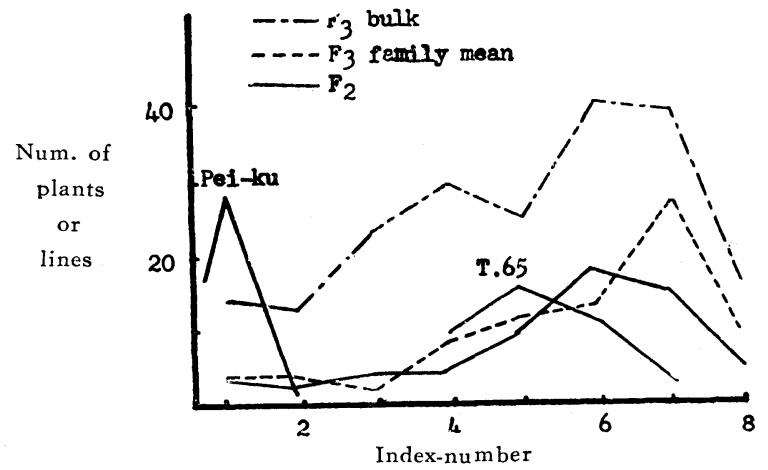

Fig. 1. Frequency distributions of index-number for resistance in $\mathrm{F}_{2}$ and $\mathrm{F}_{3}$. whether the index-numbers used are suitable or not for biometrical analysis.

It will be expected that when the effects of genes are additive on a scale, the following relation holds good.

$$
2\left(\overline{\mathrm{F}}_{3}\right)-\overline{\mathrm{F}}_{2}-\frac{1}{2}\left(\mathrm{P}_{1}+\mathrm{P}_{2}\right)=0
$$

The actual value of this formula was found to be 0.749 . The variance for this value was $4 \mathrm{VF}_{3}+\mathrm{VF}_{2}+\frac{1}{4}\left(\mathrm{~V}_{1}+\mathrm{V}_{2}\right)=0.1408$. The standard error is then 0.375 , 
and it will be found that $t=1.99$. It may then be granted to use the indexnumbers, though it may not be an ideal scale. (As stated later, the deviation in this scaling test was found to be due partly to the effect of gametic selection.)

2. Partitioning of variance components and the number of effective factors.

In accordance with Mather's method (1949), variance components were partitioned as follows:

$$
\begin{array}{rlrrr}
\mathrm{VF}_{2} & 0.5 \mathrm{D}+0.25 \mathrm{H}+\mathrm{E}_{1} & & =3.129 & 3.065 \\
\mathrm{VF}_{3} & 0.75 \mathrm{D}+0.1875 \mathrm{H}+\mathrm{E}_{1} & & =4.075 & 4.137 \\
\mathrm{VF}_{3} & 0.5 \mathrm{D}+0.0625 \mathrm{H} & +\mathrm{E}_{2} & =2.708 & 2.645 \\
\mathrm{VF}_{3} & 0.25 \mathrm{D}+0.125 \mathrm{H}+\mathrm{E}_{1} & =1.619 & 1.684 \\
\mathrm{E}_{1} & =0.365 & 0.302 \\
& & \mathrm{E}_{2} & =0.131^{*} & 0.192\left(* \text { due to } \mathrm{P}_{2}\right)
\end{array}
$$

Sum of squares of deviations $=0.0236$

Least squares solution of these equations gave the following results.

$$
\begin{aligned}
& \mathrm{D}=4.699 \pm 0.2786 \\
& \mathrm{H}=1.655 \pm 0.9694 \\
& \mathrm{E}_{1}=0.302 \pm 0.0969 \\
& \mathrm{E}_{2}=0.192 \pm 0.0912
\end{aligned}
$$

The number of effective factors was estimated by the method described by Mather (1949) as follows :

$$
\begin{aligned}
\mathrm{K}_{1} & =\frac{(\mathrm{kd})^{2}}{\mathrm{kd}^{2}}=\frac{\frac{1}{2}(6.080-1.056)^{2}}{4.699}=1.343 \\
\mathrm{~K}_{2} & =\frac{\left(\mathrm{H} \bar{V} \mathrm{~F}_{3}\right)^{2}}{\mathrm{VVF}_{3}-\frac{1}{n-1}\left(\mathrm{H} \bar{V}_{\left.\mathrm{F}_{3}\right)^{2}}\right.}=\frac{(1.382)^{2}}{1.912-0.051}=1.025
\end{aligned}
$$

These computations show that the main gene for resistance in this cross is one pair. That gene will be provisionally denoted by $B t: b t$.

\section{Change of segregation ratio due to gametic selection.}

If only one pair of genes are concerned in this cross, its effect, measured from the mid-parent point, will be evaluated as $d=\sqrt{ } \mathrm{D}=2.167$ and $\mathrm{h}=\sqrt{ } \mathrm{H}=1.287$; This value of $h$ however leads to the following mean values of $F_{2}$ and $F_{3}$ populations, which are apparently smaller than the actual values.

$$
\begin{array}{lc}
\text { (Obs. value) } \\
\overline{\mathrm{F}}_{2}=3.689+\frac{1}{2} \mathrm{~h}=4.333 & 5.552 \\
\overline{\mathrm{F}}_{3}=3.689+\frac{1}{4} \mathrm{~h}=4.011 & 4.995
\end{array}
$$

This may suggest that some faults are involved in the above computation. Looking at the frequency distributions shown in Fig. 1, we may suspect first that susceptible plants or lines are much more numerous than the number to be expected from the $1: 2: 1$ ratio. Further, as shown in Table 2, it was found that among $F_{3}$. families those showing a large variance of the index-number for resistance tended to have low fertilities in their parental $F_{2}$ plants. 
The $F_{1}$ of this cross showed semi-sterility. The hybrid sterility between distantly related varieties of rice can be explained by duplicate genes which work in the gamete as development maintainers-Gametic-Development genes or G. D. genes (Oka, $1953 \mathrm{a}, \mathrm{b})$. They bring about semi-sterility when both pairs of a set are heterozygous, due to the deterioration of double-recessive gametes. The phenomenon shown in Table 2 may be explained by assuming that the resistance gene is linked with some G. D. genes, because, when they are heterozygous, the resistance gene will produce a large variance in resistance in the progeny, and the G. D. genes will bring about sterility. And these phenomena can be combined when both of the genes behave together.

It has been shown by one of the writers (Oka, 1955) that when a gene A : a is linked with G. D. genes, if the recombination value (on the average) is $p$ and $1-2 \mathrm{p}=\mathrm{P}$, then the frequency of $\mathrm{AA}$ or aa plants in the $\mathrm{F} n$ of a hybrid can be computed by the formula

$$
\left(\begin{array}{c}
1 \\
2
\end{array}-\frac{1}{2^{n}}\right) \pm \frac{3 \mathrm{kP}}{3-\mathrm{P}}\left\{1-\left(\begin{array}{c}
\mathrm{P} \\
3
\end{array}\right)^{n-1}\right\}
$$

where $\mathrm{k}$ is a constant determined by the number of G. D. genes linked with $\mathrm{A}: \mathrm{a}$ (i. e., the number of chromosomes which cause sterility when recombined with that carrying $A: a)$. When the number of $G$. D. genes is one, $k$ is $1 / 12$, and when two, $\mathrm{k}$ is $3 / 20$. From this formula, we can derive the following formulas for the means and variances in $\mathrm{F}_{2}$ and $\mathrm{F}_{3}$.

$$
\begin{array}{lc}
\overline{\mathrm{I}}_{2}=\frac{1}{2} \mathrm{~h}+2 \mathrm{kPd} & \begin{array}{c}
\text { (Obs. value) } \\
\end{array} \\
\overline{\mathrm{F}}_{3}=\frac{1}{4} \mathrm{~h}+2 \mathrm{kP}\left(1+\frac{\mathrm{P}}{3}\right) \mathrm{d} & 1.863 \\
\mathrm{VF}_{2}=-\frac{1}{2} \mathrm{~d}^{2}+\frac{1}{4} \mathrm{~h}^{2}-4 \mathrm{k}^{2} \mathrm{P}^{2} \mathrm{~d}^{2}-2 \mathrm{kPdh}+\mathrm{E}_{1} & 3.129 \\
\mathrm{VF}_{3}=\frac{3}{4} \mathrm{~d}^{2}+\frac{3}{16} \mathrm{~h}^{2}-4 \mathrm{k}^{2} \mathrm{P}^{2}\left(1+\frac{\mathrm{P}}{3}\right){ }^{2} \mathrm{~d}^{2}-\mathrm{kP}\left(1+\frac{\mathrm{P}}{3}\right) \mathrm{dh}+\mathrm{E}_{1} & 4.075 \\
\mathrm{VF}_{3}=\frac{1}{2} \mathrm{~d}^{2}+\frac{1}{16} \mathrm{~h}^{2}-4 \mathrm{k}^{2} \mathrm{P}^{2}\left(-\frac{5}{6}+\frac{2}{3} \mathrm{P}-\frac{1}{18} \mathrm{P}^{2}\right) \mathrm{d}^{2}-\mathrm{kP}\left(1-\frac{\mathrm{P}}{3}\right) \mathrm{dh}+\mathrm{E}_{1} & 2.708 \\
\overline{\mathrm{V}}_{3}=\frac{1}{4} \cdot \mathrm{d}^{2}+\frac{1}{8} \mathrm{~h}^{2}-\frac{2}{3} \mathrm{k}^{2} \mathrm{P}^{2}\left(1+\mathrm{P}^{2}\right) \mathrm{d}^{2}-\frac{2}{3} \mathrm{kP}^{2} \mathrm{dh}+\mathrm{E}_{1} & 1.619 \\
\mathrm{WVF}_{3} / \mathrm{Frt} \cdot *-\frac{1}{12}(1-\mathrm{r}) \mathrm{P}^{2} \mathrm{~d}-\frac{1}{24}(1-\mathrm{r}) \mathrm{P}^{2} \mathrm{~h}+ & \\
\quad \frac{4}{9} \cdot(1-\mathrm{r})\left\{\mathrm{k}^{2} \mathrm{P}\left(1+\mathrm{P}^{2}\right) \mathrm{d}^{2}+\mathrm{kP} \mathrm{P}^{2} \mathrm{dh}\right\} & -0.0761
\end{array}
$$

* The co-variance of $\mathrm{F}_{3}$ family variances with $\mathrm{F}_{2}$ fertilities, calculated from Table $2 ; \mathrm{r}$ stands for the mean fertility of semi-sterile plants, and may be assumed to be 0.75 or $0.6875(=0.75+0.625 / 2)$, if linkage of one or two G.D. genes is considered (Oka 1953c).

Though these formulas arec onsiderably complicated, putting $\mathrm{k}=3 / 20, \mathrm{r}=0.6875$ (two G. D. genes were assumed on some evidence), $E_{1}=0.365$ and $E_{2}=0.131$ (found from the former calculation), and substituting for $d, h$ and $P$, respectively, $2.16+$ $\mathrm{d}^{\prime}, 2.16+\mathrm{h}^{\prime}$ and $0.667+\mathrm{P}^{\prime}$ so as to nearly satisfy the equations, they were rewritten 
Table 2. Correlation diagram between variance of $F_{3}$ families in resistance and fertility in $F_{2}$ plants.

\begin{tabular}{|c|c|c|c|c|c|c|c|c|c|c|c|c|}
\hline $\begin{array}{l}\text { Fertility } \\
\text { in } F_{2}\end{array}$ & 0 & 0.5 & 1.0 & $\begin{array}{r}\mathrm{V} \\
1.5\end{array}$ & $\begin{array}{c}\text { rianc } \\
2.0\end{array}$ & $\begin{array}{l}\text { e of } \\
2.5\end{array}$ & $\begin{array}{c}\text { fami } \\
3.0\end{array}$ & $\begin{array}{l}\text { ies } \\
3.5\end{array}$ & 4.0 & 4.4 & 5.0 & $\begin{array}{l}\text { Num. of } \\
\text { families }\end{array}$ \\
\hline 0.9 & 2 & 1 & & & 1 & & & & & & & 4 \\
\hline 0.8 & 1 & 3 & 4 & 2 & 1 & & & & & & & 11 \\
\hline 0.7 & 2 & 2 & 6 & & 1 & 1 & 1 & & 1 & & & 14 \\
\hline 0.6 & 1 & 3 & & 2 & 2 & 2 & & & 1 & & 1 & 12 \\
\hline 0.5 & 2 & & 2 & 3 & & 2 & & & & & 1 & 10 \\
\hline 0.4 & & 4 & & & & 2 & & 1 & & & & 7 \\
\hline 0.3 & 1 & 2 & 3 & 1 & & & & 1 & 1 & 1 & & 10 \\
\hline 0.2 & & 1 & & & 1 & & & & & & & 2 \\
\hline 0.1 & & & 1 & & & & & 1 & & & 2 & 4 \\
\hline Total & 9 & 16 & 16 & 8 & 6 & 7 & 1 & 3 & 3 & 1 & 4 & 74 \\
\hline
\end{tabular}

in simpler forms, and were solved by the least square method. The values of $d$, $\mathrm{h}$ and $\mathrm{P}$ thus found were as follows:

$$
\mathrm{d}=2.486 ; \mathrm{h}=2.233 ; \mathrm{P}=0.890(\mathrm{p}=0.055) \text {. }
$$

As given in Table 3 , means and variances calculated from these values agreed well with the observed values. With these values of $d, h$ and $p$, the value of $2 \overline{\mathrm{F}}_{3}-\overline{\mathrm{F}}_{2}-\frac{1}{2}\left(\overline{\mathrm{P}}_{1}+\overline{\mathrm{P}}_{2}\right)$, used for the scaling test, was found to be 1.138 ; its difference from the observed value 0.749 , was insignificant in view of its standard error 0.375 .

Table 3. Observed and expected values of means and variances in $F_{2}$ and $F_{3}$.

\begin{tabular}{|c|c|c|c|}
\hline Item & Observed value & $\begin{array}{l}\text { Expected value, } \\
\text { Considered }\end{array}$ & $\begin{array}{l}\text { Gametic selection } \\
\text { Not considered }\end{array}$ \\
\hline$\overline{\mathrm{F}}_{2}$ & 1.863 & 1.780 & 0.643 \\
\hline $\bar{F}_{3}$ & 1.306 & 1.460 & 0.322 \\
\hline $\mathrm{VF}_{2}$ & 3.129 & 2.779 & 3.065 \\
\hline $\mathrm{VF}_{3}$ & 4.075 & 4.116 & 4.137 \\
\hline $\mathrm{VF}_{3}$ & 2.708 & 2.402 & 2.645 \\
\hline $\bar{V} F_{3}$ & 1.619 & 1.844 & 1.684 \\
\hline \multirow[t]{2}{*}{$\mathrm{WVF}_{3} /$ Frt. } & -0.0761 & -0.0855 & 0 \\
\hline & $\begin{array}{c}\text { Sum of squares of } \\
\text { deviation from } \\
\text { regression }\end{array}$ & 0.243 & 1.763 \\
\hline
\end{tabular}

Further, the value of $\mathrm{K}_{1}$, which showed a deviation from 1.0 in the former calculation, was found to be 1.022 by using this value of $d$. It may then be said that by considering the change of segregation ratio due to G. D. genes, the fitness of expected values to the observed values can be much improved.

4. Linkage of the phenol-reaction gene with the resistant gene.

The parental varieties Pei-ku and Taichung No. 65 have positive-and negative phenol-reactions respectively. As the data in Table 4 (a) show, having observed the 
relation between the index-number for resistance of $F_{3}$ families and phenol-reaction of the parental $F_{2}$ plants, it was found that $F_{3}$ families with high resistance had positive phenol-reaction. This fact may indicate that the resistance gene and the phenolreaction gene are linked. Estimation of the recombination value may however be considerably awkward because of the continuous variation in index-number for resistance and the change of segregation ratio due to $G$. D. genes.

Table 4. Frequency distributions of index-number for resistance and of fertility in classes of positive and negative phenol-reaction.

(a) Index-number of $\mathrm{F}_{3}$ families.

\begin{tabular}{cccccccccccc}
$\begin{array}{c}\text { Phenol- } \\
\text { reaction }\end{array}$ & 1 & 2 & 3 & 4 & 5 & 6 & 7 & 8 & $\begin{array}{c}\text { Num. of } \\
\text { families }\end{array}$ & Mean & Variance \\
\hline+ & 3 & 3 & & 5 & 8 & 10 & 18 & 6 & 53 & 5.717 & 3.630 \\
- & & & 2 & 3 & 3 & 3 & 7 & 2 & 20 & 5.800 & 2.484 \\
\hline
\end{tabular}

(b) Fertility of $\mathrm{F}_{2}$ plants.

\begin{tabular}{cccccccccccccc}
\hline $\begin{array}{l}\text { Phenol- } \\
\text { reaction }\end{array}$ & 0.9 & 0.8 & 0.7 & 0.6 & 0.5 & 0.4 & 0.3 & 0.2 & 0.1 & $\begin{array}{c}\text { Num. of } \\
\text { plants }\end{array}$ & Mean & Variance \\
\hline+ & 4 & 6 & 11 & 7 & 7 & 6 & 10 & 1 & 2 & 54 & 0.548 & 0.046 \\
- & & 6 & 4 & 4 & 3 & 1 & & 1 & 1 & 20 & 0.610 & 0.040 \\
\hline
\end{tabular}

First, the relation between phenol-reaction and fertility in $F_{2}$ was investigated. As shown in Table 4 (b), it was found that plants with low fertilities were more numerous among positive plants than among negative plants. It then seems that the phenol-reaction gene $P h: p h$ is linked with G. D. genes. (When a gene A : a is linked with a G. D. gene $X_{1}: x_{1}$, phenotypically dominant plants have lower mean fertility and larger variance than recessive ones, since heterozygotes tend to become semi-sterile-Oka $1953 \mathrm{c}$. This is seen in Table $4 \mathrm{~b}$.)

By the method set forth by Oka $(1953 \mathrm{c})$, the linkage relation was computed. It was assumed that two pairs of G. D. genes were linked with the phenol-reaction gene $P h: p h$. Under this assumption, the frequencies of semi-sterile plants in the classes of positive and negative phenol-reactions were estimated from the differences between the two classes in mean fertility and in variance. The recombination value between $P h: p h$ and the G. D. genes was estimated to be 0.30 from those frequencies of semi-sterile plants. The recombination value between the resistance gene $B t: b t$ and the G. D. genes has already been estimated to be 0.055 . Since the linkage between $P h: p h$ and $B t: b t$ does not seem to be very tight, the order of arrangement of those genes may be assumed as follows:

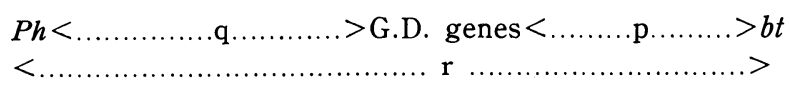

Then, denoting the recombination value between $P h: p h$ and $B t: b t$ by $\mathrm{r}$, we may expect the following gametic series in the $F_{1}$. Substituting $p=0.055$ and $q=$ 0.30 already known, it will be rewritten in a simpler form as given below on the right. 


$$
\begin{array}{ll}
P h-b t & 1-\mathrm{r}+3 \mathrm{pq}=1.0495-\mathrm{r} \\
P h-B t & \mathrm{r}+3 \mathrm{q}-3 \mathrm{pq}=0.8505+\mathrm{r} \\
p h-b t & \mathrm{r}+3 \mathrm{p}-3 \mathrm{pq}=0.1155+\mathrm{r} \\
p h-B t & 4-4 \mathrm{r}+3 \mathrm{pq}=3.9505-\mathrm{r}
\end{array}
$$

From this gametic series, the frequencies of $F_{2}$ genotypes were computed. Then, the variances of $\mathrm{F}_{3}$ family means (of index-number) in the positive and negative classes were expressed by formulas containing $r$ as the unknown quantity. The value of $r$ was estimated from the difference between variances of positive and negative classes, 1.146 (Table $4 \mathrm{a}$ ), by using those formulas. It was found to be 0.407. The resistance gene $B t: b t$ and the phenol-reaction gene $P h: p h$ seem to be linked with a recombination value around 0.4 .

\section{Discussion}

Rice varieties can be divided into the so-called Indica (or Continental) group and the Japonica (or Insular) group, and this classification seems to show the main direction of phylogenetic differentiation (Oka 1953d). Regarding the resistance to blast disease, it is known that the Indica varieties are mostly resistant, while the Japonica varieties are of ten susceptible, in so far as the leaf blast disease is concerned.

The present study proved that in a cross between the so-called Indica and Japonica varieties only one pair of genes worked as the effective factor for the difference in resistance to blast disease. It must be remembered, however, that the number of effective factors as calculated by Mather's method indicates the true number of genes only when the genes are independent and approximately the same in the magnitude of effect. If one of several genes has much more pronounced effect than the others, the other genes may be hidden behind the former in the calculation. In the present case, having computed frequency distributions of the index-number for resistance from the values of $\mathrm{d}, \mathrm{h}, \mathrm{p}$ and $\mathrm{E}$, it appeared to be a rather discontinuous one, with a gap at a certain point. The observed distributions were continuous in appearance, as already stated. This may possibly be due to the presence of some modifying genes with minor effects. It may then be inferred that in the present cross the parental varieties differ in one pair of genes with a pro. minent effect and possibly in several modifiers.

As suggested by Hashioka (1950), there may be at least a few genes with major effects for the difference between phylogenetically distant varieties in the resistance to this disease. The gene detected in the present study, provisionally named $B t: b t$, may be one of those genes determining the phylogenetic difference. It was found to be linked with the phenol-reaction gene. This linkage may be used for identification of resistance genes in future works. It may also be of some used in breeding work, though the recombination value is high. However, it should be noticed that in hybrids between distantly related varieties of rice, segregation ratios often change due to gametic selection which is caused by the Gametic-Development genes. 
In the former experiments using artificial inoculation methods, the gene for resistance was in most cases found to be dominant over its allelomorph for nonresistance. In the present cross, the gene for resistance appeared to be recessive. It is possible, however, that if the resistance genes were incompletely dominant in their intrinsic action, they would appear as dominant or as recessive according to the intensity of pathogenic agencies, since the degree of infection is easily modified by environmental conditions. The present experiment was carried out under the condition of serious natural infection, where susceptible plants were mostly killed before maturity. It may then be inferred that the gene for susceptibility Bt is not necessarily completely dominant over the resistance gene bt.

\section{Summary}

In view of the fact that hybrids between varieties of rice with different degrees of resistance to the blast disease often show a continuous array of intergrades in the degree of infection, biometrical methods were used for genic analysis of the resistance in this study. The $\mathrm{F}_{2}, \mathrm{~F}_{3}$ families and $\mathrm{F}_{3}$ bulk population of a cross between phylogenetically distant varieties, Pei-ku $\times$ Taichung No. 65, were planted in an experimental field at Tonhsu, Taichung Prefecture, Formosa, where blast disease prevails seriously. The degree of infection was measured on a single plant basis by a series of index-numbers. Variance components (D. H and E items) were partitioned by Mather's method, and the number of effective factors was estimated. Both $\mathrm{K}_{1}$ and $\mathrm{K}_{2}$ were found to approach one, indicating that the main gene segregating in this cross was one pair. Judging from the mode of frequency distribution, the gene for susceptibility appeared to be dominant over its allelomorph for resistance. It was found that the resistance gene was linked with "Gametic-Development genes" (Oka $1953 \mathrm{a}, \mathrm{b}, \mathrm{c}$ ), bringing about a change in segregation ratio. It was found further that the resistance gene was linked with the phenol-reaction gene, and the recombination value was near to 0.40 .

\section{Literature Cited}

Hashioka, Y. 1950. Studies on the mechanism of prevalence of the rice blast disease in the tropics. Taiwan Agr. Res. Inst. Tech. Bull. 8.

Nakatomi, S. 1926. On the variability and inheritances of the resistance of rice plants against the rice blast disease. Jap. Jour. Genetics. $4: 31-38$.

Oka, H. I. 1953 a. The mechanism of sterility in the intervarietal hybrid in rice. Jap. Jour. Breed. 2 (4) : 217-224.

$1953 \mathrm{~b}$. Gene analysis of intervarietal hybrid sterility and certation due to certain combinations of Gametic-Development genes. Ibid. 3 (1) : 23-30.

$1953 \mathrm{c}$. Influence of intervarietal hybrid sterility on segregation ratios in rice. Ibid. 3 (1) : $31-39$.

- $1953 \mathrm{~d}$. Variation of various characters and character combinations among rice varieties. Ibid. $3(2): 33-43$.

1955. Change of gene frequency in hybrid population of rice. Ibid. 5 (3) : 59-64.

Ramiah, K. and Ramaswami, K. 1936 : Breeding for resistance to Piricularia oryzae in rice. Proc. Ind. Aca. Sci. 3:450-458.

Sasaki, R. 1923: On the inheritance of resistance of the rice plants to the blast disease. Jap. Jour. Genet. $1: 81-85$. 